
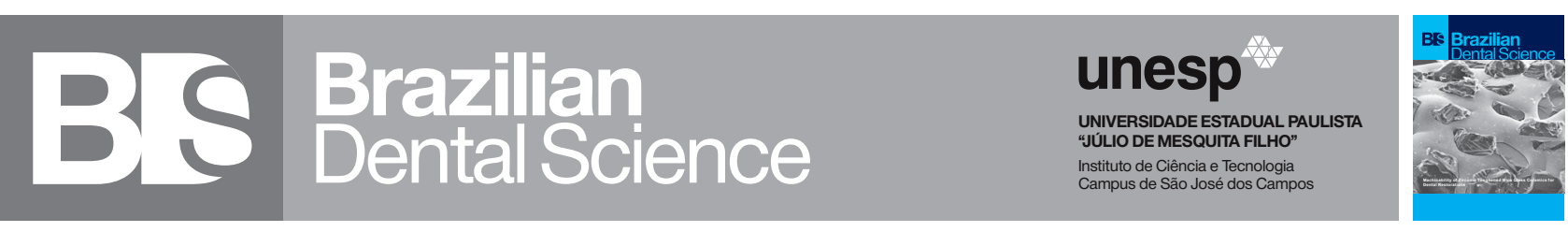

\title{
Effect antioxidants application on microshear bond strength of universal adhesive to bleached enamel
}

\author{
Efeito da aplicação de antioxidantes na resistência de união do adesivo universal ao esmalte clareado
}

Ana Luiza MACHADO ${ }^{1}$, Dayana NASCIMENTO ${ }^{1}$, Paulo Guilherme Pinheiro COELHO JÚNIOR ${ }^{1}$, Fabiana Mantovani Gomes FRANÇA ${ }^{1}$, Cecilia Pedroso TURSSI ${ }^{1}$, Roberta Tarkany BASTING ${ }^{1}$, Flávia Lucisano Botelho AMARAL ${ }^{1}$

1 - Faculdade São Leopoldo Mandic - Instituto e Centro de Pesquisas São Leopoldo Mandic - Campinas - São Paulo - Brazil.

\begin{abstract}
Purpose: To evaluate, in vitro, the influence of antioxidants (green tea extract - GT and sodium ascorbate - SA) on microshear bond strength ( $\mu$ SBS) of a universal adhesive system - self-etching mode (UAS) to bleached enamel. Material and Methods: After obtaining 50 fragments of human dental enamel ( $4 \mathrm{~mm}$ x $4 \mathrm{~mm}$ ), forty fragments were submitted to at-home bleaching technique using 10\% carbamide peroxide (Opalescence PF, Ultradent) for two h/day, for four weeks. They were randomly divided in four groups ( $\mathrm{n}=$ 10): GT - 10\% aqueous GT solution (60 min); SA - 10\% SA solution (10 min); Negative control - no antioxidant agent, immediately restored; PC1 (positive control 1) - no antioxidant agent, restored 14 days the bleaching procedure. Ten enamel fragments were assigned to PC2 group (positive control 2), in which the adhesive procedures were realized in non-bleached enamel. The UAS (Adper Single Bond Universal, 3M ESPE) was applied on enamel surface according to manufacturer's instructions and two cylinders $(0.8 \mathrm{~mm}$ diameter) of nanoparticulate composite resin (Z350, 3M ESPE) were made on each sample. After $24 \mathrm{~h}$, the cylinders were submitted to $\mu \mathrm{SBS}$ in a universal test machine $(0.5 \mathrm{~mm} /$ $\mathrm{min})$. Fracture mode was evaluated in stereomicroscope (30x magnification). SBS data, in MPa, was submitted to one-way ANOVA and fracture mode to Chi-square test $(\alpha=0.05)$. Results: There was no statistical difference between the experimental groups $(p=0.545)$ and fracture mode $(p=0.16424)$. There was predominance of adhesive fracture in all groups. Conclusion: Neither the bleaching procedure nor the application of antioxidants to bleached enamel interfered in the bond strength of the tested universal adhesive system.
\end{abstract}

\section{KEYWORDS}

Antioxidants; Dental bleaching; Shear strength.

\section{RESUMO}

Objetivo: Avaliar, in vitro, a influência de antioxidantes (extrato de chá verde - GT e ascorbato de sódio - SA) na resistência de união ao microcisalhamento ( $\mu \mathrm{SBS}$ ) de um sistema adesivo universal - modo de autocondicionamento (UAS) ao esmalte clareado. Material e Métodos: Realizou-se a obtenção de 50 fragmentos de esmalte dental humano ( $4 \mathrm{~mm}$ x $4 \mathrm{~mm}$ ), sendo que desses, quarenta fragmentos foram submetidos à técnica de clareamento caseiro utilizando peróxido de carbamida a $10 \%$ (Opalescence PF, Ultradent) por duas horas/dia, durante quatro semanas. Eles foram divididos aleatoriamente em quatro grupos $(\mathrm{n}=10)$ : Expostos a GT - solução aquosa de GT a 10\% (60 min); expostos a SA - solução 10\% SA (10 minutos); Sem exposição ao agente antioxidante e imediatamente restaurado - (controle negativo); Sem exposição ao agente antioxidante e restaurado 14 dias após o clareamento - PC1 (controle positivo 1). Os dez fragmentos de esmalte restantes foram atribuídos ao grupo PC2 (controle positivo 2), no qual os procedimentos adesivos foram realizados em esmalte não clareado. O UAS (Adper Single Bond Universal, 3M ESPE) foi aplicado na superfície do esmalte de acordo com as instruções do fabricante e dois cilindros (0,8 mm de diâmetro) de resina composta nanoparticulada (Z350, 3M ESPE) foram feitos em cada amostra. Após 24 h, os cilindros foram submetidos ao $\mu$ SBS em uma máquina de teste universal $(0,5 \mathrm{~mm} / \mathrm{min})$. O modulo de fratura foi avaliado em estereomicroscópio (aumento de 30x). Os dados do SBS, em $\mathrm{MPa}$, foram submetidos à ANOVA unidirecional e ao modo fratura ao teste do qui-quadrado $(\alpha=0,05)$. Resultados: Não houve diferença estatística entre os grupos experimentais ( $\mathrm{p}=$ $0,545)$ e modulo de fratura ( $p=0,16424)$. Houve predomínio de fratura adesiva em todos os grupos. Conclusão: Nem o procedimento de clareamento nem a aplicação de antioxidantes no esmalte clareado interferiram na resistência de união do sistema adesivo universal testado.

\section{PALAVRAS-CHAVE}

Antioxidantes; Clareamento dental; Força de cisalhamento. 
Clinical Relevance: Application of 10\% carbamide peroxide or antioxidant agents to enamel did no alter bond strength of a universal adhesive system.

\section{INTRODUCTION}

$\mathrm{T}$ ooth bleaching can be considered one of the most sought dental treatment for esthetic purposes. Chemical agents containing hydrogen peroxide or carbamide peroxide have been used for this purpose [1].

The bleaching agents are vehicles of oxygen radicals that promote oxidation of pigments embedded in the dental structure. These pigments are fractionated in minor molecular chains, being partially or totally eliminated from the dental structure by diffusion [2]. However, immediately after the dental bleaching, the residual oxygen impairs resin polymerization and, consequently, a decrease in bond strength is expected [3]. Therefore, is recommended a minimum waiting time of two weeks to make restorative procedures over bleached enamel $[3,4]$.

In order to avoid post-bleaching waiting time, the application of antioxidants immediately after bleaching, has been investigated $[5,6,7,8]$. Among the most used antioxidants, the sodium ascorbate $10 \%$ applied for ten min over the bleached tooth enamel, is one of the most studied agents. Your effectiveness for reverting the decrease in bond strength of bleached enamel has been proven, regardless of whitening gel used $[5,6]$. Another substance that has been studied is the green tea, a natural antioxidant [7, $8]$. The application of $10 \%$ green tea extract on bleached enamel was able to recover the bond strength of etch-and-rinse adhesive systems $[7,8,9]$. Furthermore, other natural antioxidants have also being studied in order to revert the bond strength values, how is the case of grape seed extract, pine bark extract, pomegranate peel extract and white tea $[10,11,12]$.

The evolution of adhesive dentistry has led to the development of new adhesive systems, called universal, that can be applied both in etchand-rinse and self-etching strategies. Most of these bond systems contain functional monomers, such as MDP (10-Methacryloyloxydecyl dihydrogen phosphate), that establishes stable ionic bonds with calcium [13]. Even considering this advantage of the universal adhesive system, it has been reported that immediate bond strength of universal adhesive to enamel bleached with carbamide peroxide $35 \%$ is decreased but recovered when treating the bleached enamel with sodium ascorbate [14].

Considering the scarcity of studies evaluating effect of other bleaching protocols, such as the at-home whitening technique, as well as the influence of antioxidants agents, like the green tea extract on bond strength of universal adhesive to bleached enamel, the purpose of this research was to evaluate, in vitro, the influence of antioxidants applied to bleached enamel on the bond strength and fracture mode of universal adhesive systems, applied on self-etching strategy, when compared to 14-days standard waiting protocol for adhesives procedures.

The null hypothesis tested was that there is no difference in the microshear bond strength of enamel and fracture mode using the universal bond system, applied in the self-conditioning mode, to the bleached enamel that received or not the application of green tea extract or sodium ascorbate, both at $10 \%$.

\section{MATERIAL AND METHODS}

\section{Ethical aspects}

This research was approved by the Research Ethics Committee of the São Leopoldo Mandic Research Institute, Campinas - SP, Brazil (CAAE $\mathrm{n}^{\circ}$ 97365918.7.0000.5374).

\section{Preparation of specimens}

Twenty-five recently extracted third human molars were selected, stored in aqueous thymol solution (0.1, pH 7.0) after the extraction, inspected under a stereomicroscope (EK3S3, São Paulo, SP, Brazil) at 30 times magnification, being discarded those with cracks and stains in the dental enamel. 
The teeth were cleaned with scalpel blades and periodontal curettes and sectioned with a flexible double-faced diamond disc (KG Sorensen, Barueri, São Paulo, Brazil) mounted on a low speed handpiece (Dabi Atlante, Ribeirão Preto, São Paulo, Brazil), separating the crown from the root. Fifty quadrangular specimens were obtained from proximal surfaces, measuring 4 $\mathrm{mm} \times 4 \mathrm{~mm}$.

The fragments were embedded in polystyrene resin (Piraglass Com Ind de Art Ornamentais, Piracicaba, SP, Brazil) in polyvinyl chloride (PVC) molds of 2.0 diameter, leaving the outer surface of the enamel exposed. After $24 \mathrm{~h}$, the specimens were removed from the molds and the enamel plates were polish in a polishing machine (Politriz Aropol 2V, Arotec, São Paulo, São Paulo, Brazil) with the decreased granulation (\#400, \#600, \#1200) of sandpaper under irrigation.

\section{Whitening procedures}

In forty fragments, the carbamide peroxide $10 \%$ whitening gel (Opalescense PF, Ultradent do Brazil, Indaiatuba, São Paulo, Brazil) was applied to the dental enamel, simulating the at-home bleaching technique. The amount of $0.02 \mathrm{~mL}$ of whitening gel was applied over each specimen using a 1-mL insulin syringe, for two h a day [15]. Subsequently, specimen was washed with distilled water and stored in artificial saliva at $37^{\circ} \mathrm{C}$. This procedure was repeated for four weeks (28 days). In the period between whitening gel applications, the specimens were kept in artificial saliva, that was renewed once a week.

Application of antioxidant agents to the bleached enamel

The forty bleached specimens were randomly divided into the following groups $(\mathrm{n}=$ 10):

- Green Tea (GT) - An aqueous solution containing green tea extract $10 \%$ was obtained. Twenty microliters $(20 \mu \mathrm{L})$ of solution was applied to dental enamel with a micropipette, for $60 \mathrm{~min}$ [7], and then rinsed with distilled water. Enamel was completely dried with absorbent papers.
- Sodium ascorbate (SA) - An aqueous solution containing sodium ascorbate $10 \%$ was manipulated was obtained. Twenty microliters $(20 \mu \mathrm{L})$ of solution was applied to dental enamel with a micropipette, for $10 \mathrm{~min}$ [5], and then rinsed with distilled water. Enamel was completely dried with absorbent papers.

- Negative control group (NC) - No antioxidant was applied to enamel. After bleaching, enamel was completely dried with absorbent papers and restored immediately.

- Positive control group 1 (PC1) - Any antioxidant was applied to enamel after bleaching procedure. The specimens were kept in artificial saliva at $37{ }^{\circ} \mathrm{C}$, for 14 days before restoration $[3,4]$.

- Positive control group 2 (PC2) - Neither the bleaching agent nor antioxidant solution were applied to enamel. Adhesive procedures were performed on intact enamel.

\section{Adhesive procedures and preparation for microshear test}

The universal adhesive system (Adper Single Bond Universal, 3M ESPE, St. Paul, MN EUA) was applied according to manufacturer's instructions (Table I), with the aid of a disposable brush (Microbrush, KG Sorensen, Cotia, São Paulo, Brazil). Light-curing was performed with a LED device with a power density of $1000 \mathrm{~mW} /$ cm2 (VALO, Ultradent, Indaiatuba, SP, Brazil), for 10 seconds. After the adhesive application, two tygon tubes (2 $\mathrm{mm}$ height) were adapted on each the surface, and inside them, it was inserted the nanoparticulate composite resin, shade A2 (Z350, 3M ESPE, St. Paul, MN, EUA), in a single increment. Light curing was performed for 20 seconds, using a LED device (VALO, Ultradent, Indaiatuba, SP, Brazil), operating with a power density of $1000 \mathrm{~mW} / \mathrm{cm}^{2}$. Table I describes main materials used in the present study. 
Table I - Pulp chamber and root canal volumes measured by ITK-Snap software according to gender

\begin{tabular}{|c|c|c|}
\hline $\begin{array}{c}\text { Material } \\
\text { (Manufacturer) } \\
\text { Batch number (\#) }\end{array}$ & Composition & Application mode \\
\hline $\begin{array}{c}\text { Bleaching gel } \\
\text { Opalescence 10\% PF } \\
\text { (Ultradent Products Inc, South Jordan, UT,USA) } \\
\text { \#D055I,D04FD, D04KH }\end{array}$ & $\begin{array}{c}\text { Carbamide Peroxide } 10 \% \text {, Potassium Nitrate, } 0.11 \% \\
\text { fluoride. }\end{array}$ & $\begin{array}{l}\text { Applied on enamel for } 2 \mathrm{~h} / \text { day, during } 28 \text { days. Light } \\
\text { cured for } 10 \text { seconds with a LED device }\left(1000 \mathrm{~mW} / \mathrm{cm}^{2}\right)\end{array}$ \\
\hline $\begin{array}{l}\text { Adhesive system } \\
\text { Adper Single Bond Universal } \\
\text { (3MESPE, St. Paul, MN, EUA) } \\
\text { \#3296401 }\end{array}$ & $\begin{array}{c}\text { Methacrylatede 2-hydroxyethyl; Bisphenol A diglycidyl } \\
\text { ether dimethacrylate; Decamethylene dimethacrylate; } \\
\text { Ethanol; Silane treated Silica; water; 1,10-Decanediol } \\
\text { phosphate methacrylate (MDP); Acrylic Copolymer and } \\
\text { itaconic acid; N,N-Dimethyl. lbenzocaine camphorqui- } \\
\text { none. }\end{array}$ & $\begin{array}{c}\text { A layer was actively applied on enamel for } 20 \text { seconds, } \\
\text { followed by gently air drying } \\
\text { For } 5 \text { seconds. Light curing was performed for } 10 \\
\text { seconds. }\end{array}$ \\
\hline $\begin{array}{c}\text { Green Tea extract 10\% aqueous solution } \\
\text { (Farmácia Santana, Itararé, SP,Brasil) } \\
\# 0256\end{array}$ & Cammelia sinensis (10\%); distilled water (90\%) & Passively applied over the enamel surface for $60 \mathrm{~min}$. \\
\hline $\begin{array}{c}\text { Sodium ascorbate } 10 \% \\
\text { aqueous solution } \\
\text { (Farmácia Santana, Itararé, SP,Brasil) } \\
\text { \#DY0261520320 }\end{array}$ & Sodium ascorbate (10\%), distilled water (90\%) & Passively applied over the enamel surface for $10 \mathrm{~min}$. \\
\hline
\end{tabular}

The restored samples kept in 100\% relative humidity in a bacteriological stove at $37{ }^{\circ} \mathrm{C}$, for $24 \mathrm{~h}$. Subsequently they were submitted to microshear test with universal test machine (EZ Test, Shimadsu, Japan) with a crosshead speed of $0.5 \mathrm{~mm} / \mathrm{min}$. The values obtained were noted in Kgf and later transformed and expressed in values of load/area (MPa). The enamel fragment was considered as experimental unit, and, therefore, of the two values obtained with the microshear test, arithmetic mean was obtained to assign a single value to the experimental unit.

\section{Fracture mode analysis}

The surfaces of the fractured specimens were examined visually using stereomicroscope (EK3S3, São Paulo, SP, Brazil) at 30 times magnification to classify the type of fracture that occurred. The fracture mode was classified as: adhesive (adhesive failure), cohesive in enamel (when there was enamel fracture, keeping adhesive interface intact), cohesive in resin (when there was fracture of the resin cylinder, keeping the adhesive interface intact) and mixed (two types of failure occurs simultaneously). Despite this classification, only the "adhesive" and "mixed" fractures were submitted to statistical analysis.

\section{Statistical analysis}

The results of the microshear test, in $\mathrm{MPa}$, were analyzed regarding its distribution. Having been found the normality of the data and homogeneity of variance between groups, the data were submitted to ANOVA one criteria. The frequencies of "adhesive" and "mixed" fractures were submitted to Chi-square test. The level of significance adopted was 0.05.

\section{RESULTS}

Regarding the bond strength data (Table II), one-way ANOVA demonstrated that there was no statistical difference between experimental groups $(\mathrm{p}=0.545)$. 
Table II - Microshear bond strength data, in MPa

\begin{tabular}{|cc|}
\hline Experimental group & Mean (standard deviation) \\
\hline GT-Green tea & $9.64(4.13)^{\star}$ \\
\hline SA - Sodium ascorbate & $11.53(2.50)^{\star}$ \\
\hline $\begin{array}{c}\text { NC - Negative control (immediately } \\
\text { restored) }\end{array}$ & $10.13(4.35)^{\star}$ \\
\hline $\begin{array}{c}\text { PC1- Positive control 1 (restored after } \\
\text { 14days) }\end{array}$ & $9.19(4.46)^{\star}$ \\
\hline PC2- Positive control 2 (not bleached) & $8.69(3.39)^{\star}$ \\
\hline
\end{tabular}

Means followed by * are statistically similar $(p>0.05)$

The results of fracture mode (Figure 1) showed no statistical differences among groups $(\mathrm{p}=0.16424)$. There was a predominance of adhesive failures in all groups. The GT and the SA groups also presented $20 \%$ and $6 \%$ of mixed fractures, respectively.

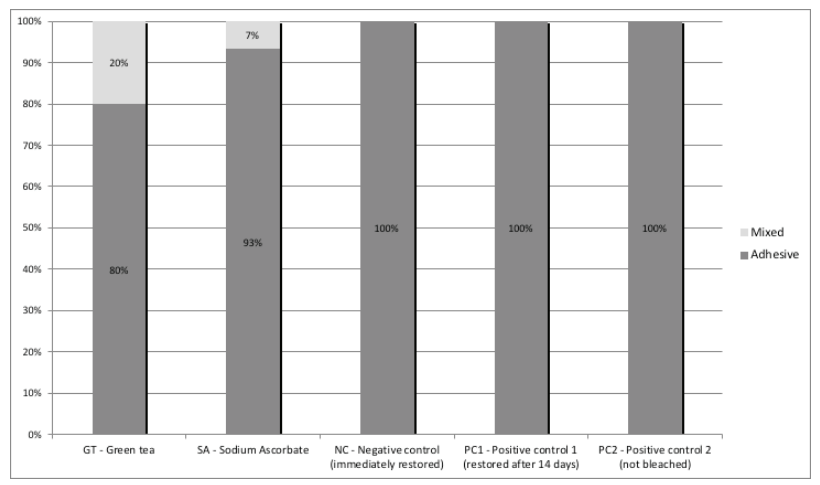

Figure 1 - Distribution of adhesive and mixed fractures among experimental groups.

\section{DISCUSSION}

The results of the present study demonstrated that there was no statistical difference between experimental groups. Therefore, the null hypothesis was accepted.

The sodium ascorbate was used as a comparison group because it is one of the most studied antioxidants, in order to revert the effects of dental bleaching on the bond strength of resin to enamel $[14,16]$. The sodium ascorbate has antioxidants properties, presents low toxicity and neutral $\mathrm{pH}$, being adequate to use in dental structures without producing undesirable damage [14]. The results are in agreement with some previous studies, that also showed no benefits from the application of sodium ascorbate to increase the bond strength of resin to enamel $[17,18]$. However, other studies claim that the application of sodium ascorbate can revert the oxidative effects promoted by the whitening gel on the dental structure $[10,12,14]$.

The difference in the results may be due to the methodology employed in these works, taking into consideration mainly the concentration of SA and GT and time of application of whitening gel and antioxidants. In the present study were used human teeth while other studies $[14,19]$ used bovine teeth. This difference in methodology may have influenced the results.

The green tea has antioxidants properties proven in the literature [13] and therefore was tested as an agent of treatment of the dental bleached structure. However, it was evident there was no difference in bond strength when applying this substance, a result that is corroborated in previous works $[18,21,22]$.

Despite the lack of effect when applying green tea to the enamel, it is important to notice that in the negative control group, where the samples were restored immediately after the bleaching, the bond strength did not decrease significantly as expected. It is speculated that the whitening gel has been applied for less time $(2 \mathrm{~h})$ than in studies $(6 \mathrm{~h})$ that found decrease of bond strength in this condition. Cavalli et al. [23] for example, applied the bleaching gel for $6 \mathrm{~h}$, during 14 days. In other study from Cavalli et al. [3], the gel was applied for $6 \mathrm{~h}$, during 10 days. Indeed, Barbosa et al. [24] concluded that in enamel that receive application of carbamide peroxide $10 \%$ for 14 days, 2 h daily, the restoration with composite resin could be realized immediately after the bleached procedure. Besides that, in other studies that verified decrease in bond strength in bleached enamel, the concentration of carbamide peroxide applied to the enamel was higher (16- 
$21 \%$ ) [21] or yet, hydrogen peroxide $38 \%$ was used in the in-office technique [12].

Still, in the present study a universal adhesive was used, which contains functional monomer in its composition, the 10-MDP (10-Metacriloixidecil dihydrogen phosphate), who is capable to establish ionic bonds with hydroxyapatite resulting in effective and stable bond strength [25]. Thus, it is speculated that the effectiveness of the adhesive on the dental enamel has overcome the deleterious effects of the whitening gel, applied for $2 \mathrm{~h}$ in the dental structure.

When analyzing the fracture mode, it was observed that the majority was adhesive, including the positive control group 2 (no bleached enamel). This result may be explained by the self-etching strategy chosen for application of the universal adhesive system, which can have led to weaker bond strength than if the previous phosphoric acid was used. In fact, the literature has reported that the phosphoric acid etching improves bonding of universal adhesives and the surface roughness of enamel [26].

Lastly, given the results of the present study, it is not yet possible to recommend the green tea aqueous solution and sodium ascorbate with the aim of revert the effects of $10 \%$ carbamide peroxide whitening gel in the dental enamel, since there was no damage in the bond strength to the enamel immediately bleached and neither benefits in the application of these agents. More studies must confirm if the application of $10 \%$ carbamide peroxide gel for shorter times than recommended by the manufacturer $(8 \mathrm{~h})$ causes significant reduction in bond strength to dental enamel, especially when using adhesives with functional monomer, such as the 10-MDP present in most universal adhesives.

\section{CONCLUSION}

In view of the results presented, it was concluded that neither the bleaching procedure nor the application of antioxidants to bleached enamel interfered in the bond strength of the tested universal adhesive system.

\section{Acknowledgements}

To CNPq (The Brazilian National Council for Scientific and Technological Development) for the financial support (grant received by the first author Ana Luiza Machado \# 143639/20188).

\section{Regulatory Statement}

This research was approved by the Research Ethics Committee of the São Leopoldo Mandic Research Institute, Campinas - SP, Brazil (CAAE n 97365918.7.0000.5374).

\section{Conflict of interest}

The authors have no proprietary, financial, or other personal interest of any nature or kind in any product, service, and/or company that is presented in this article.

\section{REFERENCES}

1. Lilaj B,Dauti R, Agis H, Schmid-Schwap M,Franz A, KanzF, MoritzA, Schedle A, CviklB.Comparison of Bleaching Products With Up to $6 \%$ and With More Than 6\% Hydrogen Peroxide: Whitening Efficacy Using Bl and WI (D) and Side Effects - An in vitro Study. Front Physiol. 2019 Aug 21;10:919. doi:10.3389/ fphys.2019.00919

2. McEvoy SA. Chemical agents for removing intrinsic stains from vital teeth. II. Current techniques and their clinical application. Quintessence Int. 1989 Jun;20(6):379-84.

3. Cavalli V, Reis AF,Giannini M, Ambrosano GM. The effect of elapsed time following bleaching on enamel bond strength of resin composite. Oper Dent. 2001Nov-Dec;26(6):597-602.

4. Miranda TA, Moura SK, Amorim VH, Terada RS, Pascotto RC. Influence of exposure time to saliva and antioxidant treatment on bond strength to enamel after tooth bleaching: an in situ study. J Appl Oral Sci. 2013 NovDec;21(6):567-74. doi: 101590/1679-775720130035.

5. KuntGE, Yılmaz N, Sen S, Dede DÖ. Effect of antioxidant treatment on the shear bond strength of composite resin to bleached enamel. Acta Odontol Scand. 2011Sep;69(5):287-91. doi:10.3109/00016357.2011.568958

6. Briso AL, Toseto RM, Rahal V, dos Santos PH, Ambrosano GM. Effect of sodium ascorbate on tag formation in bleached enamel. J Adhes Dent. 2012 Feb;14(1):19-23. doi:10.3290/j.jad.a21492 
7. Ozelin AA, Guiraldo RD, Carvalho RV, Lopes MB, Berger SB. Effects of green tea application time on bond strength after enamel bleaching. Braz Dent J. 2014 Sep-0ct;25(5):399-403. doi: 101590/0103-6440201300015

8. De Carvalho HC, Guiraldo RD, Poli-Frederico RC, Maciel SM, Moura SK, Lopes $\mathrm{MB}$, et al. Correlation between antioxidant activity and bonding strength on bleached enamel. Acta Biomater Odontol Scand. 2016 Aug 23;2(1):102-107. doi: 10.1080/23337931.2016.1222283

9. Berger SB, De Souza Carreira RP, Guiraldo RD, Lopes MB, Pavan S, Giannini $M$, et al. Can green tea be used to reverse compromised bond strength after bleaching? Eur J Oral Sci. 2013 Aug;121(4):377-81. doi: 10.1111/eos.12062

10. Subramonian R, Mathai V, Christaine Angelo JB, Ravi J. Effect of three different antioxidants on the shear bond strength of composite resin to bleached enamel: An in vitro study.J Conserv Dent. 2015 Mar-Apr;18(2):144-8. doi: 10.4103/0972-0707.153076

11. MukkaPK, Komineni NK, Pola S, Soujanya E, Karne AR, Nenavath B, Shiva S, VuppunuthulaP.An In-vitro Comparative Study of Shear Bond Strength of Composite Resin to Bleached Enamel using three Herbal Antioxidants. J Clin Diagn Res. 2016 0ct;10(10):ZC89-ZC92.

12. Rana R, Kaushik M, Sharma R, Reddy P,Mehra N. Comparative evaluation of effects of natural antioxidants on the shear bond strength of composite resin to bleached enamel. Indian J Dent Res. 2019 Jan-Feb;30(1):112-116. doi:10.4103/ ijdr.JJDR 39717

13. Van Meerbeek B, De Munck J, Yoshida Y, Inoue S, Vargas M, Vijay P et.al. Buonocore memorial lecture. Adhesion to enamel and dentin: current status and future challenges. Oper Dent. 2003 May-Jun;28(3):215-35.

14. Trindade TF,Moura LK, Raucci W Neto, Messias DC,Colucci V. Bonding effectiveness of universal adhesive to intracoronal bleached dentin treated with sodium ascorbate. Braz Dent J. 2016 May-Jun;27(3):303-8. doi: 10.1590/0103-6440201600647

15. Fernandes FP, Turssi CP,França FMG, Basting RT, Amaral FLB. Whitening mouthwash containing hydrogen peroxide decreases enamel microhardness in vitro. BJOS2017; 16:1-9.

16. Braz R, Patrício CE, Ribeiro Al, Guênes GM, Dantas DC, Montes MA, Feitosa DA Influence of antioxidants on stress of bonding agents in recently whitened teethActa Odontol Latinoam. 2011;24(3):252-7.
17. Sasaki RT,Flório FM, Basting RT.Effect of 10\% sodium ascorbate and 10\% alpha-tocopherol in different formulations on the shear bond strength of enamel and dentin submitted to a home-use bleaching treatment. Oper Dent. 2009 Nov-Dec;34(6):746-52

18. Sharafeddin F,Farshad F. The Effect of Aloe Vera, Pomegranate Peel, Grape Seed Extract, Green Tea, and Sodium Ascorbate as Antioxidants on the Shear Bond Strength of Composite Resin to Home-bleached Enamel. J Dent (Shiraz). 2015Dec;16(4):296-301.

19. Shinohara MS, Peris AR, Pimenta LA, Ambrosano GM. Shear bond strength evaluation of composite resin on enamel and dentin after nonvital bleaching. J EsthetRestor Dent. 2005;17(1):22-9.

20. Senanayake SPJN. Green tea extract: Chemistry, antioxidant properties and food applications. Journal of Functional Foods. 2013 0ct; 5(4): 1529-41. https:// doi.org/10.1016/j.jf.2013.08.011

21. Patil J, Reddy A, Venigalla BS, Shekar K, Ravichandra C, Binoy,D. Effect of different concentrations of carbamide peroxide and green tea extract on the color and shear bond strength of enamel-an in vitro study. Endodontology. 2015,27(2), p. 129-135.

22. SharafeddinF,Farshad F,Azarian B, Afshari U. Effect of Green Tea Extract as Antioxidant on Shear Bond Strength of Resin Composite to in-Office and Home-Bleached Enamel. J Dent Biomater. 2016;3 (3):269-275.

23. Cavalli V, de Carvalho RM, Giannini M. Influence of carbamide peroxide-based bleaching agents on the bond strength of resin-enamel/dentin interfaces. Braz Oral Res. 2005 Jan-Mar;19(1):23-9.

24. Barbosa CM, Sasaki RT, Flório FM, Basting RT. Influence of in situ postbleaching times on resin composite shear bond strength to enamel and dentin. Am JDent.2009 Dec;22(6):387-92

25. Yoshida Y,Nagakane K, Fukuda R, Nakayama Y,Okazaki M, Shintani H, etal. Comparative study on adhesive performance of functional monomers. J Dent Res. 2004 Jun;83(6):454-8.

26. Shimatani $Y$, Tsujimoto $A$, Nojiri K, et al. Reconsideration of Enamel Etching Protocols for Universal Adhesives: Effect of Etching Method and Etching Time. J Adhes Dent. 2019;21(4):345-354.

Prof. Dr. Flavia Lucisano Botelho do Amaral

(Corresponding address)

Faculdade São Leopoldo Mandic, Instituto e Centro de Pesquisas São Leopoldo Mandic

José Rocha Junqueira, 13, Ponte Preta, Campinas, SP, Brazil. Zip Code: 13045-755.

Date submitted: 2020 May 25

E-mail: flbamaral@gmail.com 